Archived version from NCDOCKS Institutional Repository http://libres.uncg.edu/ir/asu/

\title{
Appalacȟnan
}

B O O NE, NORTH CAROLINA

\section{Variations in the Social Networks of Forest Owners: The Effect of Management Activity, Resource Professionals, and Ownership Size}

\author{
Authors: \\ Tatyana B. Ruseva • Tom P. Evans • Burnell C. Fischer
}

\begin{abstract}
Social networks play an important role in the communication of information among forest owners and how owners process that information in making land management decisions. This article examines variations in the social network characteristics of family forest owners using survey data and interviews with 42 owners in south-central Indiana. We examine how network structure and content vary by harvesting activity, information sources, ownership attributes, sociodemographic characteristics, and location. Quantitative measures of network size and diversity, along with a qualitative understanding of network content and function are discussed and compared for active and passive forest managers. We find that active managers (people who had a recent timber harvest) had at least twice as many social ties related to forest management compared to passive managers, particularly after accounting for parcel ownership size, forest area, and total landholding size. Learning and service were the main functions of these networks, with learning being the most frequently cited reason for talking to others regardless of the management profile of forest owners. The study contributes to a growing interest in mixed methods approaches to network studies and research on social networks in private forestry.
\end{abstract}

Tatyana B. Ruseva • Tom P. Evans • Burnell C. Fischer (2014) "Variations in the Social Networks of Forest Owners: The Effect of Management Activity, Resource Professionals, and Ownership Size" Smallscale Forestry \#13 pp.377-395 Version of Record @ (DOI 10.1007/s11842-014-9260-z) 


\title{
Variations in the Social Networks of Forest Owners: The Effect of Management Activity, Resource Professionals, and Ownership Size
}

\author{
Tatyana B. Ruseva · Tom P. Evans · \\ Burnell C. Fischer
}

Abstract Social networks play an important role in the communication of information among forest owners and how owners process that information in making land management decisions. This article examines variations in the social network characteristics of family forest owners using survey data and interviews with 42 owners in south-central Indiana. We examine how network structure and content vary by harvesting activity, information sources, ownership attributes, sociodemographic characteristics, and location. Quantitative measures of network size and diversity, along with a qualitative understanding of network content and function are discussed and compared for active and passive forest managers. We find that active managers (people who had a recent timber harvest) had at least twice as many social ties related to forest management compared to passive managers, particularly after accounting for parcel ownership size, forest area, and total landholding size. Learning and service were the main functions of these networks, with learning being the most frequently cited reason for talking to others regardless of the management profile of forest owners. The study contributes to a growing interest in mixed-

\section{T. B. Ruseva (\&)}

Department of Government and Justice Studies, Appalachian State University, Ann Belk Hall 2051, Boone, NC 28608, USA

e-mail: rusevatb@appstate.edu

\section{T. P. Evans}

Department of Geography, The Vincent and Elinor Ostrom Workshop in Political Theory and Policy Analysis, Indiana University, Bloomington, IN 47405, USA

B. C. Fischer

School of Public and Environmental Affairs, The Vincent and Elinor Ostrom Workshop in Political Theory and Policy Analysis, Indiana University, Bloomington, IN 47405, USA 
methods approaches to network studies and research on social networks in private forestry.

Keywords Ego networks $\cdot$ Family forest owners $\cdot$ Network structure $\cdot$ Network diversity $\cdot$ Network content

\section{Introduction}

It is increasingly recognized that social interaction matters in natural resource decision making (Bergmann and Bliss 2004; Prell et al. 2009; Knoot and Rickenbach 2011; Kueper et al. 2013). The interactions of forest owners reflect the information and social influences shaping their management choices. In the United States, where $35 \%$ of all forests are owned by individuals and families, social interactions can provide an understanding of the actors and information pathways shaping private forest management. Land use decisions by individuals, families, estates, and other unincorporated private entities (collectively known as family forest owners) affect the capacity of forest lands to sustain ecosystem benefits, and resist threats like fire and invasive species (Butler 2008; Vokoun et al. 2010). It can be insightful to know whom family forest owners talk to and whom they turn to for advice related to the health and management of their woodlands. Understanding the social networks of forest owners can also be useful in the context of generational changes, ownership turnover, and increasingly limited resources for landowner assistance programs in private forestry.

Recently published works discuss the relative influence of social networks on forest decision making (Knoot and Rickenbach 2011), networking within forest owner cooperatives (Rickenbach 2009; Kueper et al. 2013), and communication networks during the timber sale process (Korhonen et al. 2012). These studies illustrate the role of networks in specific contexts, such as application of best management practices (BMPs) and timber sales. However, a greater understanding is needed regarding the conditions that shape the structure, content, and function of social networks. Observations about how networks vary relative to ownership characteristics and management activities are largely absent from the literature (perhaps with the exception of Korhonen et al. 2012).

The purpose of this article is to understand how diverse experiences and attributes shape the ego networks of family forest owners. Ego networks consist of the contacts an individual (ego) has with others (alters) in his or her social environment. Different landowner characteristics can be expected to condition different pathways of social interaction and, thus, different ego networks. The article addresses the following questions: (1) Who are the people forest owners talk to about land management activities? (2) How do the ego networks of forest owners vary across different landowner characteristics and experiences? and (3) How do network structure, content, and practices differ between active and passive forest managers? We focus on several sources of variation, including recent harvesting activity, use of expert sources of information, ownership and sociodemographic characteristics, and local context. The analysis relies on quantitative network 
measures, along with a qualitative understanding of network content and practices. A combination of quantitative and qualitative techniques is deemed appropriate for the exploratory nature of this study (Crossley 2010; Edwards 2010).

\section{The Ego Networks of Forest Owners}

\section{The Social Network Perspective in Private Forestry}

The utility of the social network perspective to private forestry questions lies in its ability to aid rational models of decision making with an account of the structure and content of social relations (Pescosolido 2006; Borgatti et al. 2009). From a network perspective, forest owners both act upon and react to their social environments. They have varying degrees of ability to create and maintain social ties that are determined by psychological capacities, personal experiences, and contextual constraints (Pescosolido 2006). Forest owners prioritize sources of information differently, and emphasize some social ties more than others (West et al. 1988; Knoot et al. 2010). They also hold diverse ownership values and often competing management objectives (Butler and Leatherberry 2004; Fischer and Ruseva 2010; Bengston et al. 2011).

An ego network consists of the social relations of an individual, and is treated as a separate case in the analysis. The ego network approach is useful when researchers cannot include everyone in a large community, and is especially fitting to sampling the large population of family forest owners. Social networks can be described by their structure (size, diversity, composition, brokerage, etc.), content (what flows through network ties), and function (what keeps the network alive) (Edwards 2010; Prell 2011). Qualitative researchers also focus on communication patterns and network practices (Hollstein 2011). Studies have shown that social relationships are positively associated with adoption of BMPs, willingness to coordinate management practices, and knowledge diffusion among forest owners (West et al. 1988; Warriner and Moul 1992; Prokopy et al. 2008). Ego networks were important for oak restoration practices (Knoot et al. 2010), cross-boundary cooperation (Gass et al. 2009; Sisock 2009), and innovativeness (Hujala and Tikkanen 2008; Nybakk et al. 2009). Similarly, personal contact was central in the diffusion of forest fire prevention practices (Folkman 1963; Dickerson 1971), soil conservation, and other management activities (Bultena and Hoiberg 1986).

\section{Variations in the Networks of Forest Owners}

A distinction between active and passive forest managers based on the presence of recent management activity (timber harvest) may have implications for the scope and types of social interactions. Timber harvesting is typically an indicator of how engaged owners are in the management of their woodlands (Kittredge 2005; Fischer 2012). Some individuals manage their forest land actively, others do not. The latter constitute the majority of forest owners in the United States, and are generally considered passive or reactive managers (Gass et al. 2009). Active forest managers may interact with a larger and more diverse set of people than less active managers 
because of the need for specialized skills or knowledge necessary for practices like timber marking, marketing, and harvesting. In addition, many owners may be "intentionally passive" and decide to leave the land as it is, because they treasure the non-timber values of forests (e.g. aesthetics, recreation) (Butler and Leatherberry 2004). Others may be "unintentionally passive" - unable to attend to the land because of distant residence, limited resources, age, or other incapacitating factors. A distinction between active and passive forest managers is an imperfect categorization of the diverse and dynamic nature of family forest management; nevertheless, we find it helpful for organizing our inquiry.

Landowner social interactions related to forest management may also be driven by natural disturbances (e.g. disease outbreak, storm damage) or social changes (e.g. estate settlement, divorce) (Bodin and Prell 2011). Forest owners responding to such social and/ or environmental problems are seen as previously inactive "turned" active managers due to a critical issue. These problem-driven interactions are qualified as "weak ties" or "critical issue" ties that provide access to diverse and unique resources (Granovetter 1973). We can expect active managers to have more weak ties than passive managers.

The most common sources of information for forest owners are family members, peers, foresters, and timber buyers, followed by print and online publications (Butler 2008; Hujala and Tikkanen 2008; Knoot and Rickenbach 2011). Not all owners, however, utilize these resources equally (West et al. 1988). Active managers, who are on average more experienced and informed, may be more likely than passive managers to use a resource professional (Schraml 2003). Their networks may include more professionals and be more diverse than those of passive managers. Resource professionals include people with a professional degree or training in natural resource management, such as foresters, agronomists, ecologists, or wildlife biologists, employed by government, an industry, or a private business.

Ownership and sociodemographic characteristics (age, income, etc.) are common predictors of forest owner behavior, and can be expected to shape network structure. Ownership size is related to active management, in that larger acreage owners generally tend to be more active managers (Row 1978; Straka et al. 1984). Studies show that parcel size, forest area, and ownership tenure are positively linked to harvesting (an indicator of active management), while income and education have a negative association (Alig et al. 1990; Beach et al. 2005). One can expect owners of larger parcels or with longer tenures to have larger and more diverse networks compared with owners of relatively smaller parcels or shorter tenures. Most forest owners in the United States hold $\backslash 4$ ha of forest land, and their average tenure is 26 years (Butler 2008). We can also posit that absentee owners may have less diverse and/or smaller networks than resident owners, since property residence has been connected to decreased likelihood for management activities (Vokoun et al. 2006; Joshi and Arano 2009). Finally, local institutions and county rules, such as logging permits, taxes, and zoning regulations, may create structural constraints or opportunities on social behavior because individual networks exist in multilevel environments that have their own network-like structures (Pescosolido 2006). In short, social interactions at the parcel ownership level may look different in different counties, across different sociodemographic and ownership characteristics, and between active and passive forest managers. 


\section{Methods}

\section{Study Context}

Our study site included two adjacent counties in south-central Indiana: Monroe $\left(1,064 \mathrm{~km}^{2}\right)$ and Morgan $\left(1,059 \mathrm{~km}^{2}\right)$ (Fig. 1). Private ownership in Indiana accounts for about $86 \%$ of the state's forest lands (Butler 2008). South-central Indiana is characterized by a mix of small-scale forest and agricultural land use, and offers rural amenities to a growing group of residential owners with diverse values and management strategies (Koontz 2001; Evans and Kelley 2008). Our selection of Morgan and Monroe counties was based on available survey data, proximity, and similarity in the socioeconomic and landscape characteristics. Additionally, Monroe County has a legal requirement for timber harvest permits on private lands, while no such requirement exists in Morgan County.

\section{Data Collection}

Data for this analysis consisted of a large-scale survey of landowners in south-central Indiana (CIPEC 2008). ${ }^{1}$ From the received responses $(\mathrm{N}=1,939), 629$ individuals owning parcels of minimum 2 ha indicated willingness to be contacted for a follow-up conversation. Of those, we selected 42 individuals using a stratified purposive sample for heterogeneity (Patton 2002). The following sample selection criteria were employed: (1) timber harvest in the past 5 years; (2) use of resource professionals as sources of information in making land management decisions (Table 1). ${ }^{2}$

The first criterion operationalizes our distinction between active (timber harvest) and passive forest managers (no timber harvest). Either group may or may not have used resource professionals. We recognize that some passive managers may have used experts when managing for non-timber use or farming. They may also have harvested timber over the past 7-10 years. ${ }^{3}$ This implies that our active/passive manager criterion can potentially constrain the analysis. A period longer than 5 years might have allowed a more precise measurement, but would have also undermined the reliability of survey measures. The 5-year harvesting period was selected in order to reduce recall problems and maintain consistency with the National Woodland Owner Survey (Butler 2008).

A semi-structured interview guide was developed and pretested with seven survey respondents outside the study counties. Phone interviews lasted between 15 and $60 \mathrm{~min}$ and, upon respondents' consent, were recorded using a digital call recorder from a closed-door room. Forest owners were asked to consider the people they talked to about land management using a series of free-recall, name-generating,

\footnotetext{
${ }^{1}$ An eight-page survey was mailed to 6,733 randomly selected landowners in six Indiana counties, including Monroe and Morgan counties.

${ }^{2}$ Cases were first stratified by activity and information source, then organized by county. A random number was generated for each case to help eliminate researcher's bias in the selection of cases (Patton 2002:240).

${ }^{3}$ For example, some small-scale forest owners who are generally considered active managers can go longer than 5 years between harvests.
} 


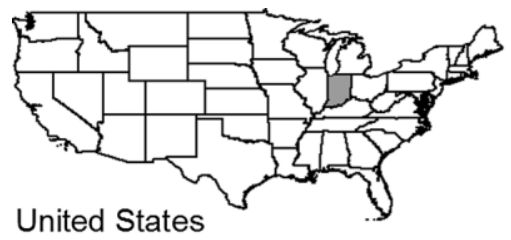

\section{State of Indiana}
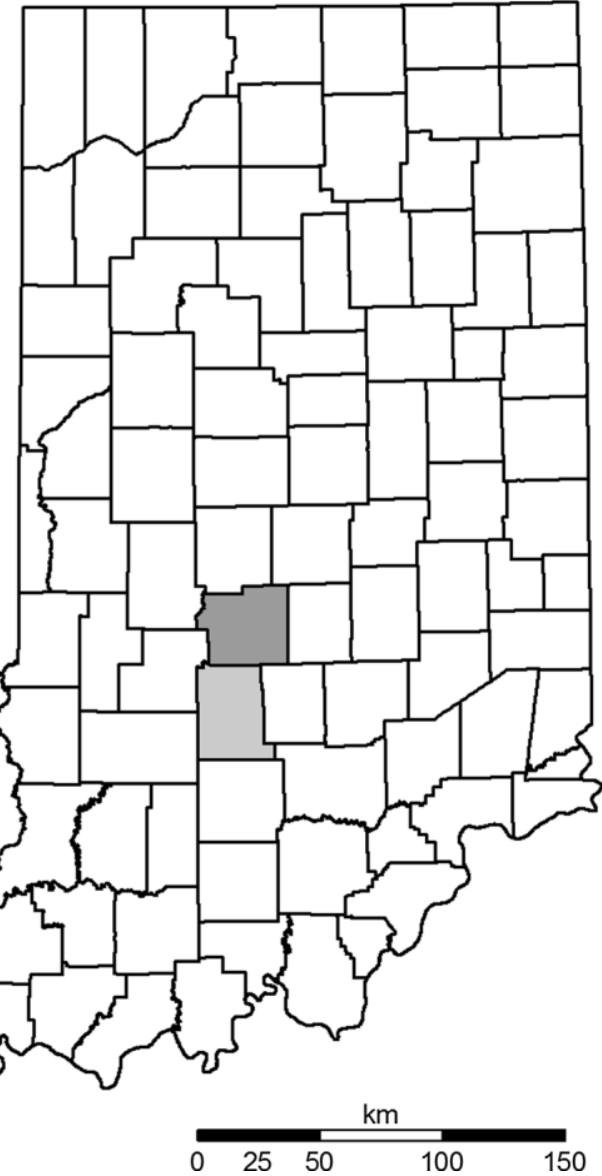

Fig. 1 Study area in south-central Indiana (CIPEC 2008)

and name-interpreting questions (Prell 2011). Network ties were elicited using first broad, then more specific position and resource name-generating questions (Online Resource 1). Other questions covered the content and function of social contacts, and knowledge about forest management.

Analysis

Our analysis combined a relational perspective with a variable-based analysis. First, measures of network structure were computed. Network size represents the number of social ties reported during the interviews (Prell 2011). Network composition measures the number of ties to specific alter groups, such as, ties to loggers, state foresters, family, neighbors, and friends. Network composition is an indicator of the 
Table 1 Stratified sample of survey respondents used in the purposive selection of forest owners $(\mathrm{n}=42)$

\begin{tabular}{|c|c|c|c|}
\hline \multirow[t]{2}{*}{ County } & \multicolumn{3}{|c|}{ Timber harvest in past 5 years } \\
\hline & Yes & No & Total \\
\hline \multicolumn{4}{|c|}{ Monroe County } \\
\hline \multicolumn{4}{|c|}{ Professional sources of information } \\
\hline Yes & $5(15)$ & $5(74)$ & 10 \\
\hline No & $4(5)$ & $6(37)$ & 10 \\
\hline Total & 9 & 11 & 20 \\
\hline \multicolumn{4}{|c|}{ Morgan County } \\
\hline \multicolumn{4}{|c|}{ Professional sources of information } \\
\hline Yes & $6(20)$ & $6(63)$ & 12 \\
\hline No & $5(8)$ & $5(30)$ & 10 \\
\hline Total & 11 & 11 & 22 \\
\hline
\end{tabular}

Value in parenthesis indicates the number of valid survey respondents in the stratum

Selection criteria based on the survey questions: "In the past 5 years, has timber been harvested from this land?" Yes, by a timber buyer or logger, or by me $=1$; No $=0$ ". "'How useful are the following sources of information to you [forestry officials, privately contracted professionals, and agriculture officials] for making land management decisions? Very useful, somewhat useful, or not useful =1; Never used =0",

range of resources that owners have access to (Lin 1982). An index of qualitative variation (IQV) for ten social groups was used to measure social diversity. ${ }^{4}$ IQV ranges from zero to one, with higher scores indicating greater diversity in the distribution of social groups ${ }^{5}$ (Knoke and Yang 2008).

Second, we examined how network size, composition, and diversity relate to landowner attributes using bivariate analysis and non-parametric tests. Nonparametric tests were employed because of the non-random nature of the data, and non-normal distribution of IQV scores (Kolmogorov-Smirnov test, $p=0.038$ ). To account for the potential for management activity, which is largely related to ownership size, we computed the weighted mean network size for active/passive managers using proportional weighting. Proportional weights allow for unbiased estimates in significant tests, particularly in stratified samples (Maletta 2007). Proportional weights were used for parcel size, forested area, and total landholding (total land owned anywhere). ${ }^{6}$

\footnotetext{
${ }^{4}$ In rare occasions alters were members of more than one group (e.g. a family member who is also a neighbor), and were assigned to the first group description (i.e. family).

${ }^{5}$ The IQV for social diversity was computed as $\mathrm{IQV}_{\mathrm{i}}=\left[1-\mathrm{Rp}_{\mathrm{j}}^{2}\right] /[(\mathrm{k}-1) / \mathrm{k}]$, where $i$ is the ego $(\mathrm{i}=1, \ldots, 42), p$ is the proportion of alters in each group $j(j=1, \ldots, 10)$, and $k$ is the number of groups listed in Table $3(\mathrm{k}=10)$ (Knoke and Yang 2008:55).

${ }^{6}$ For example: the proportional weight for parcel size is the product of a respondent's parcel size multiplied by $n / N$, where $n=42$ (sample size) and $N=$ total parcel area for the sample (i.e. the sum of parcel size for the 42 owners). The weighted mean network size was computed by multiplying each respondent's network size by his/her proportional weight, adding up the products, and dividing by the sum of weights. The formula is $\mathrm{R}\left(\mathrm{x}_{\mathrm{i}} \mathrm{w}_{\mathrm{i}}\right) / \mathrm{Rw}_{\mathrm{i}}$, where $\mathrm{x}_{\mathrm{i}}$ is a respondent's network size and $\mathrm{w}_{\mathrm{i}}$ is the proportional weight for each ownership attribute (parcel size, forested land, and total landholding size).
} 
Next, qualitative data were analyzed to identify recurring patterns related to network content, function, and practices (Boyatzis 1998). Network content encompassed the types of exchanges between respondents and social others; network function identified the purpose of these exchanges; and, network practices focused on how people create social ties (Pescosolido 2006). Free-coding and interpretive analysis helped uncover themes in the stories of forest owners (Smith et al. 2009). Finally, we used the method of analytic induction to combine the quantitative evaluation of deduced propositions with the inductive analysis of qualitative data (Patton 2002).

\section{Results}

\section{Forest Owner Attributes}

Most forest owners in our sample are male, college educated, and reside on or near their properties. Half of them are retired and rely on off-farm income, including nontimber income, from a moderate to significant degree. Over $50 \%$ of respondents have owned their land between 11 and 30 years. On average, they own 14 ha of forest land (median $=5.5$ ha; range $=80.9$ ha), and their mean parcel size is roughly 25 ha (median $=8.7$; range $=167$ ). Except for a marginal difference in the self-reported level of knowledge about forest management, results showed no significant differences in demographic and socioeconomic characteristics between the two counties ( $p$ [0.10) (Online Resource 2).

\section{Network Size and Composition}

Forest owners have on average four social ties related to the management of their land $($ mean $=3.6 ; \mathrm{SD}=2.6$; range $=11)$ (Fig. 2). Roughly one in every two owners has talked to a timber buyer, and two out of five have talked to friends and neighbors (Table 2). When confronted with a critical woodland issue, owners seek help from two people at most. In terms of the diversity of social actors, we find a medium level of network heterogeneity (mean IQV $=0.62, \mathrm{n}=39$ ). ${ }^{7}$ About one-quarter of all network ties are with resource professionals, including consulting foresters, state foresters, Department of Natural Resources employees (e.g. wildlife biologists, conservation officers), extension agents, Natural Resource Conservation Service personnel, and Soil and Water Conservation District representatives (Table 2). The measure "number of expert ties" corresponds to the above list, and excludes previous survey responses regarding use of professionals as a source of information.

\section{Variations in Network Characteristics}

We find that professional sources of information, residence, parcel and forested land size are associated with larger and more diverse ego networks (Tables 3, 4). Larger

\footnotetext{
${ }^{7}$ Three respondents had a network size of zero and were excluded from the computation.
} 
networks tend to be more diverse and to include more ties to experts (Table 4). Forest owners who have used professional sources of information tend to reach out to others when dealing with critical woodland issues (e.g. invasive plants, natural disasters). They have more critical issue ties and more expert ties than owners who had never consulted professionals (Table 3). Results, however, show no differences in network structure between the two study counties or between harvesting and nonharvesting owners ( $p$ [0.10) (Table 3).

The conventional demographic characteristics of gender, age, income, and education have no detectable relationship to network size and diversity (Table 4). Contrary to our initial expectation, we find that absentee owners, defined as those who live nearby or in a neighboring town (16 of 42), have larger and more diverse networks than resident owners (26 of 42). Absentee owners also have more ties to experts and more critical issue ties (Table 4). The story of this absentee owner provides a context for these results: "I inherited 31 acres [12.5 ha] from my uncle ..., so I've had my hands full with being a hundred miles away and haven't done a whole lot with the area that's covered with trees. [But] I had a probable poaching problem. So I called the conservation officer, and he called me the next day and said we have an arrest" (E19, M). ${ }^{8}$ Additionally, parcel size and forest acreage are related to larger and more diverse networks, more ties to experts, and more critical issue ties. Larger landholders also have more diverse networks and more critical issue ties (Table 4).

The Ego Networks of Active and Passive Managers

\section{Network Structure}

Our comparison of active and passive managers rests on the assumed relationship between management activity (timber harvest) and management potential (ownership size). The networks of forest owners who recently harvested timber are not significantly larger or more diverse than those who did not harvest. They do not contain more ties to experts either (Table 3). However, after weighting the data for relative ownership size, respondents who harvested timber have at least twice as many social ties as those who did not harvest (Table 5). Similar differences are found within the harvesting group, specifically when controlling for use of professionals, but not within the non-harvesting group. These differences can be explained by variations in the average ownership size for each subgroup, different management potentials, and motivations for timber harvests, as illustrated below.

Respondents who harvested timber, on average, had larger parcels, more forested hectares, and more land altogether than respondents who did not harvest (Table 5). Active managers with sizable parcels (e.g. 77, 103, 166 ha) and substantial forest area (e.g. 28, 38, 81 ha) had planted and harvested trees, conducted timber stand improvements, participated in forestry assistance programs, and invested time and effort in seeking assistance from professionals: "We did go through a process, I think 4 years ago, and with the help of the district [state] forester and the private

\footnotetext{
${ }^{8} \mathrm{E} 19=$ forest owner number; $\mathrm{M}=$ male $/ \mathrm{F}=$ female.
} 


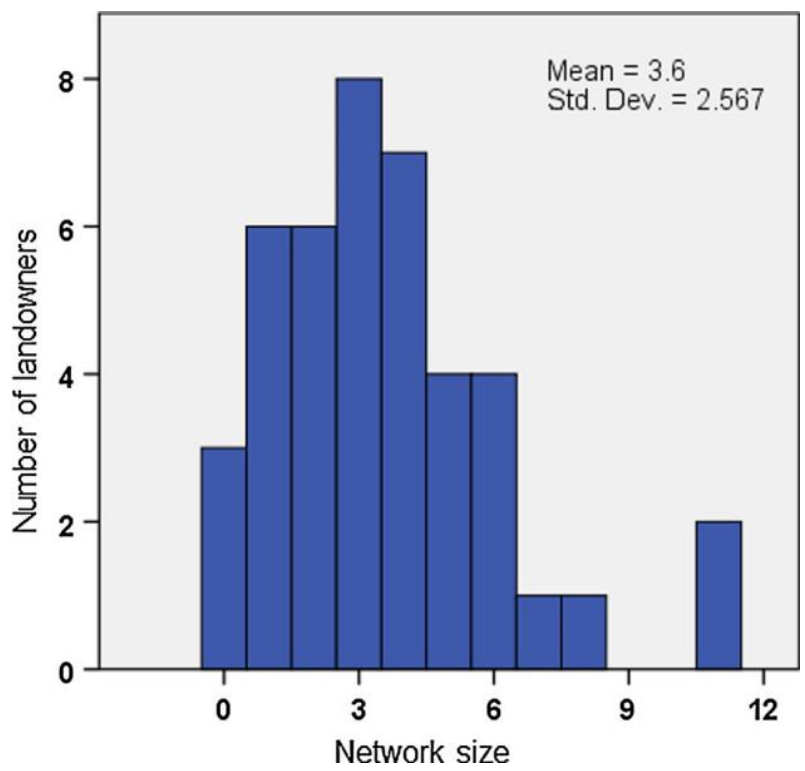

Fig. 2 Distribution of network sizes for sample forest owners $(n=42)$

Table 2 Distribution of network ties by type of actor $(n=42)$

\begin{tabular}{lccc}
\hline Network ties going to & $\begin{array}{l}\text { Number } \\
\text { of ties }(\%)\end{array}$ & $\begin{array}{l}\text { Mean number } \\
\text { of ties }\end{array}$ & $\begin{array}{l}\text { At least } \\
\text { one tie (\%) }\end{array}$ \\
\hline Timber buyers and loggers & $30(20)$ & 0.71 & $23(55)$ \\
Family members & $24(15)$ & 0.57 & $15(36)$ \\
Neighbors & $19(13)$ & 0.45 & $17(40)$ \\
Friends & $17(11)$ & 0.40 & $16(38)$ \\
Private consulting foresters & $10(7)$ & 0.24 & $10(24)$ \\
Indiana DNR employees & $10(7)$ & 0.24 & $9(21)$ \\
State foresters & $9(6)$ & 0.21 & $9(21)$ \\
Extension agents & $8(5)$ & 0.19 & $7(17)$ \\
USDA NRCS and Indiana SWCD & $2(1)$ & 0.05 & $2(05)$ \\
Others & $23(15)$ & 0.55 & $18(43)$ \\
Total & $152(100)$ & 3.6 & $126(\mathrm{n} / \mathrm{a})$
\end{tabular}

Mean number of ties $=$ number of ties divided by sample size, i.e. the average number of ties per respondent. At least one tie $=$ number and percent of respondents naming at least one member of each type of actor. DNR, Department of Natural Resources; USDA NRCS, United States Department of Agriculture Natural Resources Conservation Service; SWCD, Soil and Water Conservation District

forester had an auction which resulted in the sale of some of our timber.' (E24, M). These truly active managers had at least three more ties on average than their counterparts, who had not consulted professionals, as shown in Table 5 under weighted mean network size. The latter have harvested timber to maintain forest health; or they have harvested to build a pond, to offset the price of a land purchase, 
Table 3 Comparison of network measures by harvesting activity and type of information used in making land management decisions

\begin{tabular}{|c|c|c|c|c|c|c|c|}
\hline \multirow[t]{2}{*}{ Network measures } & \multicolumn{3}{|c|}{ Harvesting activity } & \multicolumn{3}{|c|}{$\begin{array}{l}\text { Professional sources } \\
\text { of information }\end{array}$} & \multirow[t]{2}{*}{ Total } \\
\hline & Yes & No & Diff & Yes & No & Diff & \\
\hline Size & $n=20$ & $n=22$ & & $n=22$ & $n=20$ & & $n=42$ \\
\hline Mean number of ties & 4.2 & 3.1 & 0.334 & 4.6 & 2.6 & $0.006 * *$ & 3.6 \\
\hline Standard deviation & 3.0 & 2.0 & n.a. & 2.7 & 2.0 & n.a. & 3.0 \\
\hline Total number of ties & 84 & 67 & n.a. & 101 & 50 & n.a. & 151 \\
\hline Diversity & $n=20$ & $n=19$ & & $n=22$ & $n=17$ & & $n=39$ \\
\hline Mean IQV & 0.61 & 0.63 & 0.639 & 0.68 & 0.53 & 0.115 & 0.62 \\
\hline Standard deviation of IQV & 0.3 & 0.3 & n.a. & 0.3 & 0.3 & n.a. & 0.3 \\
\hline \multicolumn{8}{|l|}{ Composition } \\
\hline Mean number of "expert" ties & 1.1 & 0.8 & 0.715 & 1.6 & 0.2 & $0.000 * * *$ & 0.9 \\
\hline Mean number of harvesting ties & 1.1 & 0.8 & 0.285 & 1.1 & 0.8 & 0.109 & 1.0 \\
\hline $\begin{array}{l}\text { Mean number of } \\
\text { tree-planting ties }\end{array}$ & 0.7 & 0.6 & 0.838 & 0.7 & 0.6 & 0.908 & 0.6 \\
\hline $\begin{array}{l}\text { Mean number of } \\
\text { "critical issue" ties }\end{array}$ & 0.5 & 0.2 & 0.104 & 0.6 & 0.1 & $0.036 * *$ & 0.3 \\
\hline
\end{tabular}

$I Q V$ index of qualitative variation, Diff difference between groups in the sample based on Mann-Whitney $\mathrm{U}$ test

$* p \backslash 0.10 ; * * p \backslash 0.05 ; * * * p \backslash 0.01$

or respond to the impact of an infrastructure project: "The absolutely, only reason we contacted those individuals [timber companies] was the pipeline coming through. We had no intention of harvesting these trees. Ever" (E16, M); "So if a tree falls ... or if it's hit by a lightening I harvest it. If some trees are growing too close together and they might be a little healthier if they are thinned out and the canopy might improve, then I do that as needed" (E21, M). This reactive management approach suggested some similarities with the subset of nonharvesting respondents who had used professional sources of information (Table 5). In comparison, most forest owners who reported no harvest had smaller parcels on average, with a few forested hectares, used primarily for residence, recreation, and wildlife enjoyment (Table 5): "I have about 5 acres [2 ha] of natural woods behind the house, so, [I] just let it be and try to keep trees for the animals and birds", (E36, M); “We have only 8 acres [3.2 ha]. It's woods and it's our home .... We're not doing anything like selling wood or trying to get rid of wood. I mean I want my trees"' (E11, F). While some passive managers opposed logging, others (particularly owners with sizable forest holdings) were interested in a harvest but had reservations about the trustworthiness of loggers: "Well, I look in the paper occasionally and look at the names of the timber people and I know that not all of them are trustworthy. So rather than expose myself to some anguish because of dealing with some non-trustworthy person, I just let them go" (E18, M). On average, these intentionally passive managers had three social ties (Table 5). 
Table 4 Correlations between network measures and forest owner attributes

\begin{tabular}{|c|c|c|c|c|}
\hline Measures and attributes & Network size & Network diversity & Expert ties & Critical issue ties \\
\hline \multicolumn{5}{|l|}{ Network measures } \\
\hline Network size & - & $0.864 * * *$ & $0.721 * * *$ & 0.280 \\
\hline Network diversity & $0.864 * * *$ & - & $0.777 * * *$ & 0.093 \\
\hline "Expert" ties & $0.721 * * *$ & $0.777 * * *$ & - & 0.265 \\
\hline "Critical issue" ties & 0.280 & 0.093 & 0.265 & - \\
\hline \multicolumn{5}{|l|}{ Landowner attributes } \\
\hline Age (years) & -0.120 & -0.227 & -0.046 & 0.006 \\
\hline Gender $(1=$ male, $2=$ female $)$ & 0.069 & -0.086 & -0.180 & -0.046 \\
\hline Income $^{\mathrm{a}}$ & -0.189 & 0.054 & -0.044 & -0.035 \\
\hline Education $^{\mathrm{b}}$ & -0.053 & 0.094 & 0.053 & -0.027 \\
\hline Level of knowledge ${ }^{c}$ & -0.007 & 0.036 & 0.100 & 0.092 \\
\hline Place of residence ${ }^{\mathrm{d}}$ & $0.359 * *$ & $0.433 * * *$ & $0.410 * * *$ & $0.670 * * *$ \\
\hline Ownership tenure (years) & 0.005 & -0.178 & 0.040 & 0.135 \\
\hline Parcel size (hectares) & $0.372 * *$ & $0.368 * *$ & $0.316^{* * *}$ & $0.332 * *$ \\
\hline Forested land (hectares) & $0.318 * *$ & $0.300^{*}$ & $0.258 *$ & $0.315 * *$ \\
\hline Total landholding (hectares) & 0.225 & $0.300 *$ & 0.184 & $0.281 *$ \\
\hline
\end{tabular}

${ }^{a}$ Income in 2008 , based on a seven-point scale: $1=$ Under $\$ 15,000 ; 2=\$ 15,000-\$ 29,999$; $3=\$ 30,000-\$ 44,999 ; \quad 4=\$ 45,000-\$ 59,999 ; \quad 5=\$ 60,000-\$ 74,999 ; \quad 6=\$ 75,000-\$ 89,999$; $7=\$ 90,000$ or more

${ }^{\mathrm{b}}$ Education level based on a five-point scale: 1 = High school or equivalent, 2 = Some college or technical training, 3 = Associate degree, 4 = Bachelor degree, $5=$ Post-bachelor degree

${ }^{\mathrm{c}}$ How knowledgeable are people in your household about land management activities like, timber harvesting and tree planting? $1=$ Not at all; $2=$ Not very; $3=$ Somewhat; $4=$ Very

${ }^{\mathrm{d}}$ Correspondence between landowner's address and parcel address: 1 = On property; 2 = Near property; 3 = Nearby town; 4 = Out of county

$* p \backslash 0.10 ; * * p \backslash 0.05 ; * * * p \backslash 0.01$ (two-tailed) Spearman's rho used to compute measures of association

Further differences between subsets of active and passive managers are illustrated by the network visualizations given in Online Resources 3 and 4 (Borgatti 2006).

The comparisons among subsets of forest owners illustrate the fluid nature of the distinction between active and passive managers. The story of this owner, who reported no harvest, illustrates some imperfections: "Well, we own acres in several different places. Where we live now, we have 20 acres [ 8 ha] and then we have 40 acres [16 ha] in Clay and Owen Counties. On two of the properties we really haven't done a lot of management in the last 5 to 7 years. But on the property we sold in Owen County, we decided to sell some timber before we sold it, ... it was actually more of a financial decision" (E8, F). This case motivated a comparison of mean network size, weighted by total landholding size, which revealed a significant difference in the weighted mean number of ties for harvesting and non-harvesting respondents (Table 5). To sum, the weighted measures of mean network size, along with the stories of forest owners, suggest that ownership size is an important antecedent of management activity and, consequently, level of social interaction. 
Table 5 Ownership size and simple and weighted mean network size by harvesting activity, controlling for sources of information $(\mathrm{n}=42)$

\begin{tabular}{|c|c|c|c|c|c|c|c|c|c|c|}
\hline \multirow[t]{3}{*}{ Landowner attributes } & \multicolumn{3}{|c|}{ Timber harvest } & \multicolumn{3}{|c|}{ No timber harvest } & \multicolumn{3}{|l|}{ All } & \multirow[t]{3}{*}{ Total } \\
\hline & \multicolumn{3}{|c|}{ Used professional sources of information } & \multicolumn{3}{|c|}{ Used professional sources of information } & \multirow[t]{2}{*}{ Harvest } & \multirow[t]{2}{*}{ No harvest } & \multirow[t]{2}{*}{ Diff } & \\
\hline & Yes & No & Diff & Yes & No & Diff & & & & \\
\hline Size & $n=11$ & $n=9$ & & $n=11$ & $n=11$ & & $n=20$ & $n=22$ & & $n=42$ \\
\hline Total number of ties & 58 & 26 & 32 & 43 & 25 & 18 & 84 & 68 & 16 & 152 \\
\hline Mean number of ties & 5.3 & 2.9 & 2.4 & 3.9 & 2.3 & $1.6^{* *}$ & 4.2 & 3.1 & 1.1 & 3.6 \\
\hline Ownership & $n=11$ & $n=9$ & & $n=11$ & $n=11$ & & $n=20$ & $n=22$ & & $n=42$ \\
\hline Mean parcel size (ha) & 36.9 & 23.5 & 13.4 & 20.0 & 17.6 & 2.4 & 30.9 & 18.8 & 12.1 & 24.5 \\
\hline Mean forested land (ha) & 12.5 & 19.8 & -7.3 & 9.4 & 16.2 & -6.8 & 15.8 & 12.8 & 3.0 & 14.2 \\
\hline Mean total landholding (ha) & 44.4 & 25.0 & 19.4 & 23.7 & 23.9 & -0.2 & 35.7 & 23.8 & 11.9 & 29.5 \\
\hline \multicolumn{11}{|l|}{ Mean network size weighted by } \\
\hline Parcel size & 8.3 & 4.0 & $4.3 * * *$ & 3.7 & 2.4 & 1.3 & 6.8 & 3.1 & $3.7 * * *$ & 5.3 \\
\hline Forested land & 7.0 & 4.3 & $2.7 * *$ & 3.9 & 2.4 & 1.5 & 5.4 & 2.9 & $2.5 * * *$ & 4.2 \\
\hline Total landholding & 7.3 & 4.0 & $3.3 * *$ & 3.8 & 1.6 & $2.2 *$ & 6.2 & 2.7 & $3.5 * * *$ & 4.7 \\
\hline
\end{tabular}

Diff mean differences between groups with designated significance levels based on Mann-Whitney U test

$* p \backslash 0.10 ; * * p \backslash 0.05 ; * * * p \backslash 0.01$ 


\section{Content and Function}

The content of forest owner networks included one or more of the following: (1) information about invasive species, names of loggers, local nurseries, etc.; (2) assistance, including logging, selective cutting and removal, erosion control; and (3) legal consultations and grievances related to timber theft, illegal hunting, asset transactions, destructive harvesting, infrastructure development, and eminent domain. While half of the respondents ( 21 of 42 ) pointed to technical assistance, the majority (32) identified information as the main content of their networks. Approximately onethird of owners (12) received or sought legal consultation.

The main functions of forest owner networks were learning and service. Learning was the most frequently cited reason for talking to others. The majority of active managers (harvesting group) and about half of passive managers (non-harvesting group) indicated a need to learn, specifically how to better manage their woodland, support a healthy woodland, grow better hardwood species, or whom to hire for a certain job. The desire to learn is demonstrated in this passive manager's outlook: "Who is it, when I decide that I want to harvest my timber that I consult with, in order that I do that in an environmentally sustainable manner?" (E7, M). Roughly half of active managers and fewer than one-third of passive managers described their networks as serving a purely applied function, namely to provide technical service or equipment. Network functions were not mutually exclusive and many owners looked for both learning and service in their interactions with others.

\section{Networking Practices}

Personal traits, psychological capacities, and context influence the network practices of forest owners. An interviewee explained how she and her spouse differed in their approaches to information seeking: "He is better at the networking part. He's more social of the two of us. I am more likely to get on the Internet or I'm more likely to go down to the extension office... I am more likely to gather those kinds of resources, while he's more likely to do the networking, person-to-person talking", $(\mathrm{E} 14, \mathrm{~F})$. Many owners had not consulted others because of distrust in resource professionals, disinterest in timber production, or strong preference for no management: "I haven't really what you'd call it management. It is as it is" $(\mathrm{E} 34, \mathrm{M})$. Others were compelled to work with people in response to a critical issue affecting their woodland, such as infrastructure projects, development, or a property purchase. Learning was the primary function of these network practices that often included professionals: "In purchasing the property I sought out advice from the state and federal service providers, the Soil and Water Conservation, the DNR and the Geological Survey ... and sought to educate myself" (E35, M); "We did hire a private consultant to assess the impact to our trees and he provided us with a report... [with] information on our property that I would like to have known anyways. It was an education for me." (E16, M).

The most immediate sources of information for forest owners were local contacts, friends, and neighbors - a finding corroborated in our quantitative (Table 3) and qualitative analyses. In the words of this owner, "You start by asking friends and 
neighbors, then if you need contact the local DNR or county agent for further information" (E27, M). Forestry professionals were contacted when individuals had specific questions pertaining to timber marking, harvesting, invasive plants, disease, timber incursion, or infrastructure projects: "Well, that was my contact with $\mathrm{X}$ [the private forester] — primarily to find out what value we had and whether it was worth a harvest" (E2, M).

Active forest managers had more streamlined network practices than passive managers. In response to whom they talk to about management activities like timber harvests or tree planting, this active manager offered the following: "I start by visiting with my wife and four adult children to learn of their interest in exploring improved timber harvest management practice and then I contact the district forester, who's a district forester for Monroe County. Then we also have a friend of our son who is in the timber business .... I suppose I also would review a periodical on good forest management practice. I would check a periodical that gets sent to us quarterly that discusses timber values and current practices in Indiana. Those would be the four different groups that I'd consult', (E24, M). As a comparison, a passive manager described her networking approach as follows: "The people I have contacted and think of contacting or have spoken, you know asked for their opinion, include a landscape architect, whose father-in-law happened to timber land. We have received information in the mail. As far as tree planting goes I have contacted the DNR. I have looked online. And I talk to a family member. Well..., they are both a neighbor and family", (E10, F).

\section{Discussion and Conclusion}

Taken together, our findings indicate that the ego networks of active forest managers (people who have had a timber sale) are larger and more diverse than those of passive managers, when weighted by ownership parcel, forest area, and total landholding size. Combined with an emphasis on learning, the ego networks of active managers have the potential to be an important mechanism for shaping private forest management decisions. For those forest owners who do nothing and/or interact with no one when it comes to the management of their woodland, interpersonal relationships hold little promise for landowner engagement. Because most woodland owners in America are not managing their land with input from a natural resource professional or guidance from a written management plan, or are otherwise disinterested and unreachable (Butler et al. 2007; Rickenbach et al. 2011), it may be important to begin thinking how to access these individuals outside the realm of forest management (e.g. landscaping, land transactions).

Three aspects of forest owner networks warrant discussion here. First, the network composition is similar to that identified in research on forest owner networks in the United States and Finland (Rickenbach 2009; Knoot and Rickenbach 2011; Korhonen et al. 2012). In these studies, and here, timber buyers and loggers are most typical network members, followed by family members and peers. Additionally, in our study, resource professionals as a collective group constitute over one-quarter of all social 
ties. ${ }^{9}$ We see the presence of two typical groups of network members: timber industry representatives, and a variety of public and private resource professionals. Contacts with the latter are particularly important because they can condition subsequent paths of social interaction. Individuals who use professionals as sources of information tend to reach out to others for advice in dealing with critical forestry issues, which also seems to diversify their networks (Tables 3,4). This is comparable to the role of forestry professionals in mediating information and influencing owner behavior, discussed in past research (West et al. 1988).

Second, our findings have relevance for thinking about education among forest owners. Information seeking and learning were the most frequent reasons for talking to others according to respondents in this study. Learning often took place alongside management activities, in the presence of resource professionals, or trusted friends. It is common among forest owners, particularly in Finland and Sweden, to rely on forestry professionals and to trust their services (Hujala et al. 2007; Hujala and Tikkanen 2008; Nordlund and Westin 2011). That reliance is less typical among participants in this study, and certainly among many forest owners in the United States, who are generally skeptical of forestry professionals (Rickenbach et al. 2005). This finding suggests that knowledge sharing and learning - both important functions of forest owner networks - are unlikely to take place in the absence of a trusted individual, be it a forester or a peer. Trust is critical to any learning outcome, as seen here and in research on peer-to-peer networks (Rickenbach 2009; Fischer et al. 2010; Kueper et al. 2013).

Third, ownership size, rather than harvesting activity seems to drive variations in forest owner networks. As illustrated by our quantitative and qualitative results, the effect of harvesting activity on network size is mediated by parcel size, forest area, or total landholding size. This is consistent with past work suggesting that active forest owners are likely to have larger parcels with substantial forest area (Rickenbach 2009; Kittredge et al. 2013). Forest acreage is a likely indicator of an owner's capacity and propensity to manage his/her woodland and to work with others. Our results reflect this connection and suggest that land-as a physical boundary (parcel size) and space (residence) — can serve as a bridging factor between landowners and social others. In addition, the prominence of "critical issue" or weak ties (Granovetter 1973) for larger parcel owners indicates that more land can enable access to more diverse sources of information.

The study results should be considered with several caveats. First, one should recognize the limited generalizability of the findings. Our results are primarily applicable to forest owners in south-central Indiana, but some broad insights also appear about the networks of family forest owners elsewhere. To begin, respondents' sociodemographic (age, education) and ownership (size, tenure) attributes are generally similar to those reported in the National Woodland Owner Survey (Butler 2008). Additionally, the land-use dynamics in our study area are characteristic of those observed in other parts of the Midwest United States (Evans and Kelley 2008; Knoot et al.2010). Some parallels also exist between the share of family forests in Indiana and

\footnotetext{
9 This may be an indication of the importance of the Indiana district foresters, who have a long history of a quality program.
} 
that in Norway, Finland, and Sweden, as well as the demographic and cultural diversity among forest owners in the United States and Sweden (Fischer et al. 2010; NFF 2013). Nevertheless, the average size of forest holdings in the Nordic countries is twice that of Indiana, and associational life among Swedish and Norwegian forest owners stands in stark contrast to the individualism and limited collective action initiatives of forest wners in the United States (Rickenbach et al. 2005; NFF 2013). Many small-scale forest owners in the Nordic countries are members of forest owner associations, which effectively facilitate social interactions, information distribution, and access to training and professional assistance (Fischer et al. 2010).

The reliability of some of the network measures should also be noted. The process of collecting ego network data poses a significant recall burden, and time constraints during the interviews may have resulted in omitted social ties, a common challenge in network studies (McCarty et al. 2007). Another caveat is that network structures and processes are dynamic and nearly always imperfect. An observed network, known as the "achieved" network, can differ from the true network in the sense that it fails to measure potentially important alter-ego ties or alter attributes (Heath et al. 2009). A greater challenge in this study was the comparison of networks using an active/passive management distinction, which in practice is often blurred and changing. As researchers contend, a network is "an evolving social world, a world of meanings, conventions, resources," shaped by past events and histories (Crossley 2010:31). This observation is particularly fitting in the context of private forest management, which is rooted in a dynamic social-ecological system. This study, therefore, provides a nuanced picture and only a partial snapshot of the complex set of relationships shaping social interactions on family forest lands in the Midwest United States.

Acknowledgments We gratefully acknowledge support from the Center for the Study of Institutions, Population, and Environmental Change, Indiana University, through funding from the Human and Social Dynamics program at the National Science Foundation (grant BCS0624178).

\section{References}

Alig RJ, Lee KJ, Moulton R (1990) Likelihood of timber management on nonindustrial private forests: evidence from research studies. General Technical Report SE-60. USDA Forest Service, Southeast Forest Experiment Station, Asheville, NC

Beach RH, Pattanayak SK, Yang JC, Murray BC, Abt RC (2005) Econometric studies of non-industrial private forest management: a review and synthesis. For Policy Econ 7(3):261-281

Bengston D, Asah S, Butler B (2011) The diverse values and motivations of family forest owners in the United States: an analysis of an open-ended question in the National Woodland Owner Survey. Small Scale For 10:339-355

Bergmann SA, Bliss JC (2004) Foundations of crossboundary cooperation: resource management at the public-private interface. Soc Nat Resour 17(5):377-393

Bodin O, Prell C (2011) Social networks and natural resource management: uncovering the social fabric of environmental governance, 1st edn. Cambridge University Press, New York

Borgatti SP (2006) E-NET software for the analysis of ego-network data. Analytic Technologies, Needham, MA

Borgatti SP, Mehra A, Brassm DJ, Labianca G (2009) Network analysis in the social sciences. Science 323(5916):892-895 
Boyatzis RE (1998) Transforming qualitaitive information: thematic analysis and code development. Sage Publications, Thousand Oaks, CA

Bultena GL, Hoiberg EO (1986) Sources of informatoon and technical assistance for farmers in controlling soil erosion. In: Lovejoy SB, Napier TL (eds) Conserving soil: insights from socioeconomic research. Soil Conservation Society of America, Ankeny, IA, pp 71-82

Butler BJ (2008) Family forest owners of the United States, 2006. General Technical Report NRS-27. USDA Forest Service, Northern Research Station, Newtown Square, PA. www.treesearch.fs.fed.us/ pubs/15758

Butler BJ, Leatherberry EC (2004) America's family forest owners. J For 102(7):4-14

Butler BJ, Tyrrell M, Feinberg G, Van Manen S, Wiseman L, Wallinger S (2007) Understanding and reaching family forest owners: lessons from social marketing research. J For 105(7):348-357

CIPEC (Center for the Study of Institutions, Population, and Environmental Change) (2008) A survey of forest and land management in south-central Indiana. Indiana University, Bloomington, CIPEC

Crossley N (2010) The social world of the network: combining qualitative and quantitative elements in social network analysis. Sociologica 1:1-34

Dickerson B (1971) Communicating fire prevention messages effectively. J For 69:812-813

Edwards G (2010) Mixed-method approaches to social network analysis. NCRM Discussion Paper. Report No. NCRM/015. National Centre for Research Methods, University of Manchester. http:// eprints.ncrm.ac.uk/842/

Evans TP, Kelley H (2008) Assessing the transition from deforestation to forest regrowth with an agentbased model of land cover change for south-central Indiana. Geoforum 39(2):819-832

Fischer AP (2012) Identifying policy target groups with qualitative and quantitative methods: the case of wildfire risk on nonindustrial private forest lands. For Pol Econ 25:62-71

Fischer BC, Ruseva TB (2010) What is happening in and outside America's private woodlands? J For 108(6):304-306 (Invited Response to Coufal et al. J For 108(6):301-304)

Fischer AP, Bliss J, Ingemarson F, Lidestav G, Lönnstedt L (2010) From the small woodland problem to ecosocial systems: the evolution of social research on small-scale forestry in Sweden and the USA. Scand J For Res 25:390-398

Folkman W (1963) Levels and sources of forest fire prevention knowledge of California hunters. Res. Paper PSW-11. Pacific Southwest Forest and Range Experiment Station, Berkeley, CA. http:// treesearch.fs.fed.us/pubs/29557

Gass R, Rickenbach M, Schulte L, Zeuli K (2009) Cross-boundary coordination on forested landscapes: investigating alternatives for implementation. J Environ Manag 43(1):107-117

Granovetter MS (1973) The strength of weak ties. Am J Sociol 78(6):1360-1380

Heath S, Fuller A, Johnston B (2009) Chasing shadows: defining network boundaries in qualitative social network analysis. Qual Res 9(5):645-661

Hollstein B (2011) Qualitative approaches. In: Scott J, Carrington PJ (eds) The Sage handbook of social network analysis. Sage, London, pp 404-417

Hujala T, Tikkanen J (2008) Boosters of and barriers to smooth communication in family forest owners' decision making. Scand J For Res 23(5):466-477

Hujala T, Pykäläinen J, Tikkanen J (2007) Decision making among Finnish non-industrial private forest owners: the role of professional opinion and desire to learn. Scand J For Res 22(5):454-463

Joshi S, Arano KG (2009) Determinants of private forest management decisions: a study on West Virginia NIPF landowners. For Pol Econ 11:118-125

Kittredge DB (2005) The cooperation of private forest owners on scales larger than their individual property: international examples and potential application in the United States. For Pol Econ 7:671-688

Kittredge DB, Rickenbach MG, Knoot TG, Snellings E, Erazo A (2013) It's the network: how personal connections shape decisions about private forest use. North J Appl For 30(2):67-74

Knoke D, Yang S (2008) Social network analysis, 2nd edn. Sage, Thousand Oaks, CA

Knoot T, Rickenbach M (2011) Best management practices and timber harvesting: the role of social networks in shaping landowner decisions. Scand J For Res 26(2):171-182

Knoot T, Schulte L, Rickenbach M (2010) Oak conservation and restoration on private forestlands: negotiating a social-ecological landscape. J Environ Manag 45(1):155-164

Koontz TM (2001) Money talks - but to whom? Financial versus nonmonetary motivations in land use decisions. Soc Natur Resour 14:51-65

Korhonen K, Hujala T, Kurttila M (2012) Reaching forest owners through their social networks in timber sales. Scand J For Res 27(1):88-99 
Kueper AM, Sagor ES, Becker DR (2013) Learning from landowners: examining the role of peer exchange in private landowner outreach through landowner networks. Soc Natur Resour 28:912-930. doi:10. 1080/08941920.2012.722748

Lin N (1982) Social resources and instrumental action. In: Marsden P, Lin N (eds) Social structure and network analysis. Sage, Beverly Hills, CA, pp 131-145

Maletta H (2007) Weighting: Raynald's SPSS tools. http://www.spsstools.net/Tutorials/WEIGHTING. pdf

McCarty C, Killworth PD, Rennell J (2007) Impact of methods for reducing respondent burden on personal network structural measures. Soc Networks 29:300-315

NFF (Nordic Family Forestry) (2013) Facts on forests in Denmark, Finland, Norway, and Sweden. http:// www.nordicforestry.org/default.asp (right column)

Nordlund A, Westin K (2011) Forest values and forest management attitudes among private forest owners in Sweden. Forests 2:30-50

Nybakk E, Crespell P, Hansen E, Lunnan A (2009) Antecedents to forest owner innovativeness: an investigation of the non-timber forest products and services sector. Forest Ecol Manag 257(2):608-618

Patton MQ (2002) Qualitative research and evaluation methods, 3rd edn. Sage, Thousand Oaks, CA

Pescosolido BA (2006) Sociology of social networks. In: Bryant CD, Peck DL (eds) The handbook of 21st century sociology. Sage, Thousand Oaks, CA, pp 208-217

Prell C (2011) Social network analysis: history, theory and methodology. Sage, Thousand Oaks, CA

Prell C, Hubacek K, Reed M (2009) Stakeholder analysis and social network analysis in natural resource management. Soc Natur Resour 22(6):501-518

Prokopy LS, Floress K, Klotthor-Weinkauf D, Baumgart-Getz A (2008) Determinants of agricultural best management practice adoption: evidence from the literature. J Soil Water Conserv 63(5):300-311

Rickenbach M (2009) Serving members and reaching others: the performance and social networks of a landowner cooperative. For Pol Econ 11:593-599

Rickenbach M, Zeuli K, Sturgess-Cleek E (2005) Despite failure: the emergence of "new" forest owners in private forest policy in Wisconsin, USA. Scand J For Res 20(6):503-513

Rickenbach M, Schulte LA, Kittredge DB, Labich WG, Shinneman DJ (2011) Cross-boundary cooperation: a mechanism for sustaining ecosystem services from private lands. J Soil Water Conserv 66(4):91A-96A

Row C (1978) Economies of tract size in timber growing. J For 76:576-582

Schraml U (2003) Expectations towards forestry: the influence of personal networks with forest owners. Urban For Urban Greening 1(3):161-170

Sisock ML (2009) Private forest owners' communication networks: exploring the structural basis for cross-boundary cooperation. Ph.D. thesis. University of Wisconsin-Madison

Smith JA, Flowers P, Larkin M (2009) Interpretative phenomenological analysis: theory, method, and research. Sage, Thousand Oaks, CA

Straka TJ, Wisdom HW, Moak JE (1984) Size of forest holding and investment behavior of nonindustrial private owners. J For 82:495-496

Vokoun M, Amacher GS, Wear DN (2006) Scale of harvesting by non-industrial private forest landowners. J For Econ 11:223-244

Vokoun M, Amacher GS, Sullivan J, Wear D (2010) Examining incentives for adjacent non-industrial private forest landowners to cooperate. For Pol Econ 12(2):104-110

Warriner GK, Moul TM (1992) Kinship and personal communication network influences on the adoption of agriculture conservation technology. J Rural Stud 8(3):279-291

West PC, Fly JM, Blahna DJ, Carpenter EM (1988) The communication and diffusion of NIPF management strategies. North J Appl For 5:265-270 